\title{
EFFECTS OF FORMING TOOLS AND PROCESS PARAMETERS ON SURFACE ROUGHNESS IN INCREMENTAL SHEET FORMING
}

\author{
Umair Khalil', Muhammad Haris Aziz', Mirza Jahanzaib', \\ Wasim Ahmad', Salman Hussain' ${ }^{1}$, Faisal Hafeez ${ }^{1}$ \\ 1 Department of Industrial Engineering, University of Engineering \& Technology Taxila, Pakistan \\ e-mail: umairkhalil007@gmail.com, haris.aziz@uettaxila.edu.pk,mirza.jahanzaib@uettaxila.edu.pk, \\ wasim.ahmad@uettaxila.edu.pk,salman.hussain@uettaxila.edu.pk, faisalhafeez.ie@gmail.com
}

Received: 2018.03 .18 Accepted: 2018.08.01 Published: 2018.09.01

\begin{abstract}
Literature has vastly advocated for incremental sheet forming as a significant process for formation of sheet metal components, because of its higher formability in comparison with the rest of metal forming processes such as deep drawing and stamping. Due to high formability of incremental sheet forming it becomes important to investigate the main factors, influencing the quality of forming products. However, less attention has been given to investigate the inconsistencies reflected often in determining the effect of multiple forming parameters and parametric interactions comprising of spindle rotational speed and feed rate, tool size and sheet thickness, sheet thickness and step depth. This study investigates the effect of various principal factors including tool type, tool size, sheet thickness, spindle speed, feed rate, step increment including and their respective interaction on surface roughness. Research data was collected by undertaking extensive literature review of previous studies on incremental sheet forming regarding surface quality. A quantitative one way analysis of variance (ANOVA) was employed to analyze the significance and contribution of factors influencing surface quality of sheet forming. The findings highlight the contribution of forming parameters and their combined interactions on surface roughness. Based on the empirical findings, this study derives implications for the optimization of tool type, parametric interactions among principal factors and their respective optimized operational range for incremental sheet forming.
\end{abstract}

Keywords: ISF, quantitative survey, forming tools, forming parameters, surface roughness.

\section{INTRODUCTION}

Sheet metal forming is as old as human learned the use of metals. With advance in science and technology, forming methods have been evolved to form the desired complex shape products and improving the strength of metals. For forming, mostly sheet metals are ductile in nature which could be formed up to a specific limit. Beyond this limit, fracture occurs which is consider as part failure. Surface roughness is considered a weak point for incremental sheet forming (ISF) products. Surface finish is represented by the large scale waviness created by the tool path and the small scale roughness induced by large surface strains. The surface quality is influenced by several process parameters.

Incremental sheet forming (ISF) removes the use of punch and die. It is a die less process so, friction between forming tool and sheet metal is less. In incremental sheet forming (ISF), deformation process is local in nature and gradual which highly influence the surface roughness. 
Research has been led into changes of basic incremental sheet forming process. As an example, others forming methods like hot incremental sheet forming have been investigated in order to reduce forming force. Duflou et al. [1] utilized laser mechanism in order to improve surface finish and increase maximum wall angle of titanium aluminum alloy (TiAL6V4) blank. Similar titanium composite was heated with band radiators installed in sheet holder by Palumbo et al. [2] observed the improvement in surface finish of that alloy. In recent years, use of electric incremental forming method have been investigated and applied to different materials such as aluminum alloy (AA 6061) by Adams et al. [3] and titanium aluminum alloy (TiAL6V4) used by Fan [4] with decrease in roughness. Due to its high formability, incremental sheet forming (ISF) is used in different industrial applications. For automotive industry various asymmetric complex parts were made as rapid prototyping like reflective surface of head lights, service panels, and hood and fenders. , incremental sheet forming (ISF) can also be used for non-automotive industrial applications like aerospace industries, biomedical applications (ankle support, cranial plate) and appliances (solar cooker) etc.

Due to its importance and significance lot of research has been done and is going on. In order to highlight its research trend, data base used for search literature was google scholar and science direct. Key words employed were "incremental sheet forming (ISF)". We observed that 89 publications were carried out from 2000-2005, 457 researches have been examined from 2005-2010, 1490 publications have been observed from
2010-2015, 829 researches were seen from 2015 2017. The rising trend about incremental sheet forming (ISF) has been observed in recent years. It is expected that the number will keep growing in coming years.

Continuing too much publications pose a challenge to researchers to sort the required parameters for desired formability especially when there are contradicting findings. For instance, Durante et al. [5] found that surface roughness decreases as tool tip diameter increases on the same site other tests demonstrated that tool diameter has no significant effect on roughness as Bagudanch et al. [6] and Deepak et al. [7] suggested that roughness decreased with increase in sheet thickness. From these, Gulati et al. [8] and Shanmuganatan et al. [9] discovered that roughness decreased with decrease in sheet thickness. However, ambiguity in experiment requires high attention to look at the results from the others papers related to these parameters.

Most important inconsistencies that observed while investigating the conclusions were about the effect of forming tools and other forming parameters. Li et al. [10] investigated that ball tool has better surface finish than hemispherical tool on the other hand Durante M. [5] demonstrated that hemispherical tools provide better surface finish as compared to ball tool. Similarly, Cawley et al. [11] examined that parabolic tools reduced roughness while inverse results of angular tools about surface finish as Adams [12]. Therefore, there was a need to conduct a comprehensive literature review on tool and other forming parameters to investigate their effects on Roughness.

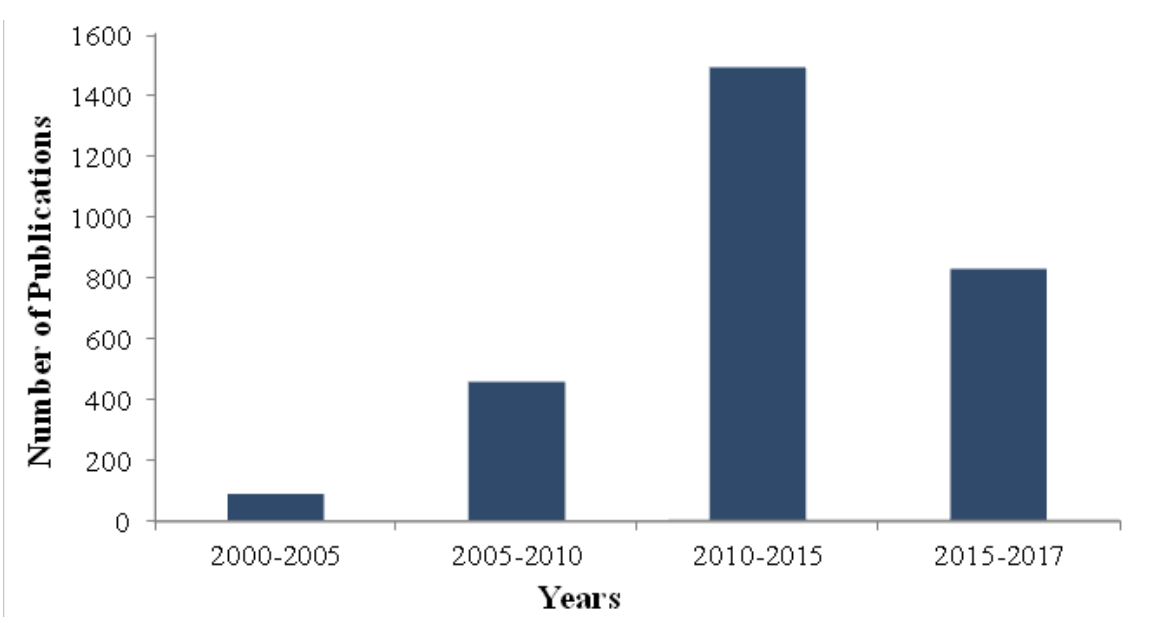

Fig. 1. Incremental sheet forming (ISF) research trend 


\section{HYPOTHESIS}

What does this survey say in regards to the impacts of forming tools and others process parameters for enhancing surface roughness? Is there any difference or consistency between various conclusions? Different hypotheses have been drawn regarding the effect on roughness, particularly how the variation of these process parameters minimizing roughness? Following conclusions that are considered in this review are given below as:

- Null hypothesis $\left(\mathbf{H}_{\mathbf{0}}\right)$ : Forming parameters have no effect on roughness.

- Alternate hypothesis $\left(\mathbf{H}_{1}\right)$ : At least one parameter has significant effect on roughness.

- $\quad \mathbf{H}_{1}$ (a): Tool types have significant effect on roughness.

- $\quad \mathbf{H}_{1}$ (b): Tool size has significant effect on roughness.

- $\quad \mathbf{H}_{1}$ (c): Sheet thickness has significant effect on roughness.

- $\quad \mathbf{H}_{1}$ (d): Step increment has significant effect on roughness.

- $\mathbf{H}_{1}(\mathbf{e})$ : Feed rate has significant effect on roughness.

- $\quad \mathbf{H}_{1}(\mathbf{f})$ : Spindle speed has significant effect on roughness.

- $\quad \mathbf{H}_{1}(\mathrm{~g})$ : Interaction (tool diameter and sheet thickness) has significant effect on roughness.

\section{METHODOLOGY}

This survey was conducted as 'organized quantitative review' about incremental sheet forming parameters. This sort of survey has been defined by Pickering and Byrne [13]. This survey practice has been tried by various students and researchers and gets repeated and best outcomes. This procedure is very beneficial to the incremental sheet forming process parameters because of quantitative idea about input data and will be seen in tabular form, permits successful comparison of process parameters values between various papers. In this survey paper, some of selected process parameters have been considered, because these parameters are basic in every incremental sheet forming process, other particular incremental process like electric and hot incremental forming also included is this survey and output parameters that considered is roughness.

A large number of papers were searched for incremental sheet forming. For this study, papers were selected according to some specified crite- ria i.e. recent papers, original research, published journal papers which included various incremental sheet forming (ISF) process parameters excluding review papers. Summary of papers that were used in this survey database were process parameter values, tool and sheet material, bibliographic information and results and discussion. Data is presented in tabular form and papers are referenced. For simplicity and better understanding, authors name and numerical reference which will separate papers with same author and reference. For example, Ham et al. [14] and Ham and jesweit [15]. In the data tables, if some information about any process parameter was not given, then it is expressed as N/A in tables.

Following conclusions that are considered in this review are given below as:

- Increasing process parameters value will decrease roughness.

- Decreasing process parameters value will decrease roughness.

- Optimized process parameters value will decrease roughness.

- No effect of process parameters values on roughness.

Analysis of variance (ANOVA) is used in order to analyze the input data. Analysis of variance (ANOVA) is a statistical method used to investigate experimental data and make decisions about process parameters under study. It is used to classify significant process parameters and to measure their effects on response like roughness. It is also very helpful in determining the percentage contribution of each parameter against an expressed level of certainty.

Experimental incremental sheet forming (ISF) parameters have been studied in order to investigate their effects on roughness. Results and discussion is performed for each parameter and also examined interaction effect, after the results of tables about each process parameter. Next section describes the parameters comparison on roughness. End discussion was conducted which concluded the whole findings of this survey paper. Finally, future scope of work and overall conclusions were presented.

\section{EXPERIMENTAL FORMING PARAMETERS}

This survey paper investigates fundamental forming process parameters for incremental sheet forming, also included hot, electric and laser forming. Several methods are available for analyzing the data collected from experiment. 
Table 1. Tool type's levels

\begin{tabular}{|c|c|c|c|c|c|c|}
\hline Hemi spherical & Spherical & Flat & Parabolic & Water jet tool & Ball tool & Angular tool \\
\hline 0 & 1 & 2 & 3 & 4 & 5 & 6 \\
\hline
\end{tabular}

Table 2. Response (Roughness) Levels

\begin{tabular}{|c|c|c|}
\hline Increase & Decrease & No effect \\
\hline 1 & 2 & 0 \\
\hline
\end{tabular}

Table 3. Input Factors and their levels

\begin{tabular}{|c|c|c|c|c|}
\hline Sr.no & Factors Units Levels & $\begin{array}{c}\text { Low Range [0] } \\
(\mathbf{m m})\end{array}$ & $\begin{array}{c}\text { Medium Range [1] } \\
(\mathbf{m m})\end{array}$ & $\begin{array}{c}\text { High Range [3] } \\
(\mathbf{m m})\end{array}$ \\
\hline 1 & Tool size & $1-10$ & $11-15$ & 16 \\
\hline 2 & Sheet thickness & $.1-.8$ & $.9-1.5$ & 1.6 \\
\hline 3 & step increment & $.1-.4$ & $.5-.8$ & $.9-1$ \\
\hline 4 & Feed rate & $100-1200$ & $1250-2400$ & 2450 \\
\hline 5 & Spindle speed & $100-2000$ & $2100-4000$ & 4050 \\
\hline 6 & Interaction & $1-1.5$ & $1.6-2$ & $2.1-2.5$ \\
\hline
\end{tabular}

However, statistical methods should be used to analyze the data so that results and conclusions are objective. Analysis of variance (ANOVA) is widely used to test the statistical significance of the effects through fisher method ( $F$-test). In this study qualitative data classified the item into different categories like increase or decrease and good or bad. If response (roughness) obtained from experiments is in the form of qualitative data, then the problem is that how to analyze data. In order to analyze data through analysis of variance (ANOVA), first convert input data into different classes hemispherical, spherical or flat as 0 , 1 or 2 etc respectively.

For example in case of tool types we classify tool shapes into different numbers as shown in Table 1.

Similarly, roughness achieved from these tool types were also classified into different classes as no effect, Increasing or decreasing roughness as 0,1 or 2 respectively in Table 2 .

For others forming process parameters Design of experiment was developed at 3- levels in Table 3 and analyze the results with the help of analysis of variance (ANOVA) to see the significance of these process parameters on roughness. Forming parameters and their ranges were classified and low, medium and high indicated as 0,1 , 2 respectively in order to design experiment, as shown in Table 3.

\section{RESULTS AND DISCUSSIONS}

\section{Forming tool characteristics}

Initially, two types of forming tools have been used in incremental sheet forming process. First one is rigid hemispherical tool and the other is rotating ball end tool, enabling it to roll freely over forming parts [16]. With the growth in incremental sheet forming field, flat end, angular and other forming tool profiles were developed [11].

Cawley et al. [11] and Kim et al. [17] and Petek et al. [18] showed that one kind of forming tool has more advantageous over the other kind of forming tool in terms of surface quality and formed parts accuracy. Two parameters forming tool shapes and tool size were considered in this survey paper. Forming mechanism was significantly influenced by forming tool profiles and tool size. Tool shape and tool size mainly influence the contact area between forming sheet and tool interface that creates friction [5] and forming forces [5].

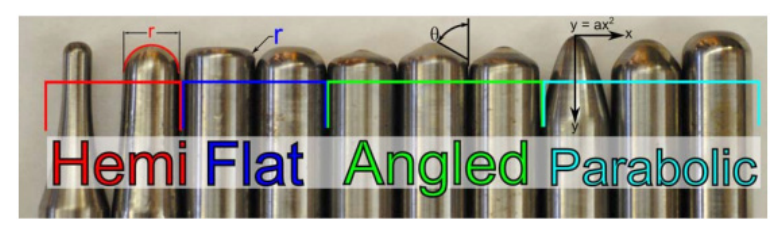

Fig. 2. Forming tool profiles [12] 
Forming tools are made from different materials like tool steel, carbide and high speed steel (HSS). Lubrication between forming sheet and tool affects the friction condition during forming process [19].
Presently no papers have been found that investigate specifically the influence of tool materials on roughness. So, we have not considered the effect of tool materials on formability in this survey.

Table 4. Tools types paper summary

\begin{tabular}{|c|c|c|c|c|c|}
\hline $\begin{array}{l}\text { Papers: Author\& } \\
\text { reference }\end{array}$ & Tool types & $\begin{array}{l}\text { Tool } \\
\text { types } \\
\text { levels }\end{array}$ & Tool material & $\begin{array}{c}\text { Output measure } \\
\text { (Effects on roughness) }\end{array}$ & $\begin{array}{l}\text { Roughness } \\
\text { levels }\end{array}$ \\
\hline Prashant [20] & Hemispherical & 0 & N/A & $\begin{array}{l}\text { High roughness as compared to flat } \\
\text { tool. }\end{array}$ & 1 \\
\hline Pengtao [21] & Hemispherical & 0 & $\begin{array}{c}\text { Q235 } \\
40 \mathrm{Gr} \\
\text { Hard alloy } \\
06 \mathrm{cr} 19 \mathrm{Ni10}\end{array}$ & $\begin{array}{c}\text { Hardness of tool tip material is } \\
\text { smaller, roughness will be larger and } \\
\text { vice versa. }\end{array}$ & 1 \\
\hline Cawley [11] & $\begin{array}{l}\text { Parabolic heads of } \\
\text { various shapes }\end{array}$ & 3 & Tool steel & $\begin{array}{l}\text { Increasing in surface quality with } \\
\text { increased coefficient. }\end{array}$ & 2 \\
\hline Cawley [11] & Flat end tools & 2 & Tool steel & Increased surface quality. & 2 \\
\hline Khare [22] & Spherical tools & 1 & N/A & $\begin{array}{l}\text { Better surface finish compared to } \\
\text { hemispherical tool due to rolling ac- } \\
\text { tion instead of rubbing. }\end{array}$ & 2 \\
\hline Kim [17] & $\begin{array}{l}\text { Hemi spherical and } \\
\text { rolling ball tool }\end{array}$ & 0 & N/A & $\begin{array}{c}\text { Ball end tool with lubrication leave no } \\
\text { surface scratches, while hemi spheri- } \\
\text { cal tool without lubrication left most } \\
\text { surface scratches. }\end{array}$ & 2 \\
\hline Ziran [23] & $\begin{array}{c}\text { Flat end tool and } \\
\text { hemi spherical tool }\end{array}$ & 2 & $\begin{array}{l}\text { High speed } \\
\text { steel(HSS) }\end{array}$ & $\begin{array}{l}\text { Flat end tool provide better profile } \\
\text { accuracy than hemispherical end } \\
\text { tool. }\end{array}$ & 2 \\
\hline Petek [18] & $\begin{array}{l}\text { Rigid tool(RTSPIF), } \\
\text { Water jet tool } \\
\text { (WJSPIF) }\end{array}$ & 4 & N/A & $\begin{array}{l}\text { Rigid tool gives higher process accu- } \\
\text { racy and short machining time than } \\
\text { water jet tool. }\end{array}$ & 1 \\
\hline Lu [24] & $\begin{array}{c}\text { Oblique roller } \\
\text { ball(ORB) and } \\
\text { Rigid hemi } \\
\text { spherical(RHS) tool }\end{array}$ & 5 & $\mathrm{~N} / \mathrm{A}$ & $\begin{array}{l}\text { Roller ball tool have better surface } \\
\text { quality than over hemi spherical tool. }\end{array}$ & 2 \\
\hline Ham [25] & $\begin{array}{l}\text { Acetal tool tip vs } \\
\text { Carbide tool tip }\end{array}$ & 7 & $\mathrm{~N} / \mathrm{A}$ & $\begin{array}{l}\text { With Acetal tool, absence of burnish } \\
\text { and step down ridges, and high isot- } \\
\text { ropy of surface roughness. Carbide } \\
\text { tool produces smoother surfaces. }\end{array}$ & 2 \\
\hline Cavaler [19] & $\begin{array}{l}\text { Coated tool } \\
\text { uncoated tool }\end{array}$ & 7 & $\begin{array}{l}\text { Titanium alloy } \\
\text { (TiAIN) }\end{array}$ & $\begin{array}{l}\text { Coated tools have less surface } \\
\text { roughness than uncoated tool. }\end{array}$ & 1 \\
\hline Chinnaiyan [26] & $\begin{array}{l}\text { Ball end tool } \\
\text { Hemispherical }\end{array}$ & 5 & $\begin{array}{l}\text { EN medium } \\
\text { carbon steel }\end{array}$ & $\begin{array}{l}\text { Ball tool with lubrication has better } \\
\text { surface finish than hemispherical } \\
\text { tool. }\end{array}$ & 2 \\
\hline Adams [12] & Parabolic $\left(10 x^{2}\right)$ & 3 & $\begin{array}{l}\text { ASTM A81 tool } \\
\text { steel }\end{array}$ & $\begin{array}{l}\text { Smoothest surface can be produced } \\
\text { than any other tool profiles }\end{array}$ & 2 \\
\hline Li [10] & $\begin{array}{c}\text { Ball tool solid } \\
\text { hemispherical tool }\end{array}$ & 5 & N/A & $\begin{array}{l}\text { Better surface finish of ball tool than } \\
\text { hemi spherical tool. }\end{array}$ & 2 \\
\hline Adams [12] & Flat tools & 2 & $\begin{array}{l}\text { ASTM A81 tool } \\
\text { steel }\end{array}$ & Increased surface quality. & 2 \\
\hline Durante [5] & $\begin{array}{l}\text { Rotating ball tool, } \\
\text { Solid Hemispheri- } \\
\text { cal tool }\end{array}$ & 5 & N/A & $\begin{array}{c}\text { Hemispherical tool gives higher } \\
\text { surface roughness as compared to } \\
\text { ball tool. }\end{array}$ & 1 \\
\hline Adams [12] & Angular tools & 6 & $\begin{array}{l}\text { ASTM A81 tool } \\
\text { steel }\end{array}$ & Reduction in surface quality. & 1 \\
\hline Adams [12] & Parabolic tools & 3 & $\begin{array}{c}\text { ASTM A81 tool } \\
\text { steel }\end{array}$ & Low surface roughness. & 2 \\
\hline Yazar [27] & $\mathrm{N} / \mathrm{A}$ & N/A & (HNS,MS,WPS) & $\begin{array}{l}\text { Harder the tool hardness, will gives } \\
\text { smaller the roughness. }\end{array}$ & N/A \\
\hline
\end{tabular}


Table 5. ANOVA for forming tool shapes

\begin{tabular}{|c|c|c|c|c|c|}
\hline Model & Sum of Squares & dof & Mean square & F & Sig. \\
\hline Between groups & .61 & 1 & .61 & 6.73 & .02 \\
\hline Within groups (error) & 1.09 & 12 & .09 & & \\
\hline Total & 1.71 & 13 & & & \\
\hline
\end{tabular}

Significance level $=\alpha=.05$

\section{Forming tool shapes}

Few papers compared various shapes of forming tools that determines their effect on surface roughness. The target of this survey is additionally to buildup comprehension of how incremental sheet forming tools shapes influence the forming attribute like surface roughness. Main focus is given to the effects of various tool shapes which have not yet been illustrated.

The summery of effects of these tools on surface roughness is given in Table 4.

Analyze the results with the help of ANOVA in Table 5.

\section{Factor significance Criteria:}

- Factor will be significant if $\mathrm{P}$ value $<\alpha$ $\Rightarrow .02<.05$ (Condition satisfied)

- Hence, Null hypothesis $\left(\mathrm{H}_{\mathrm{o}}\right)$ should be rejected

- Contribution $=(.61 / 1.71) \times 100=36 \%$

It means that Alternate hypothesis $\left(\mathrm{H}_{1}\right)$ should be accepted. Therefore, tool shapes has significant effect in terms of surface quality. Li et al. [10] and Kim et al. [17] compared roller ball tool and hemispherical tools by using straight groove test (SGT) in order to quantify their effects on surface roughness. Other researcher Durante et al. [5] expressed that such kind of test is not the real indicator of actual deformation of incremental forming process. Durante suggested that hemispherical tool gives higher surface roughness as compared to ball tool.

The others issue that were examined by comparing the solid hemi spherical tool without rotation, with rolling ball tool, it will be seen that rolling ball tool is more advantageous than hemispherical tools in terms of roughness. A careful understanding about the various shapes of forming tools on surface quality and will permits the clients of sheet forming process to choose the best tool for every specific forming requirement.

\section{Forming tool size}

There were 20 journal papers were found in this survey paper that describe the effects of forming tool size on surface roughness. Most of the papers claimed that with increase in tool tip diameter surface roughness decreased. 3 papers suggested that an optimized value of tool diameter decreased surface roughness. Only one paper was seen that presented that forming tool size has insignificant effect on surface roughness. No paper was seen that claimed that with decrease in tool size surface roughness decreased.

Table demonstrates the summery of each paper, with extra information about sheet material, tool material and experiment replications.

Summery of papers is given in the Table 6 .

Shanmuganatan et al. tetsted various tool diameter combined with step increment on AA 3003$O$ sheet and analyzed that with increasing the tool diameter surface roughness decreased [32].

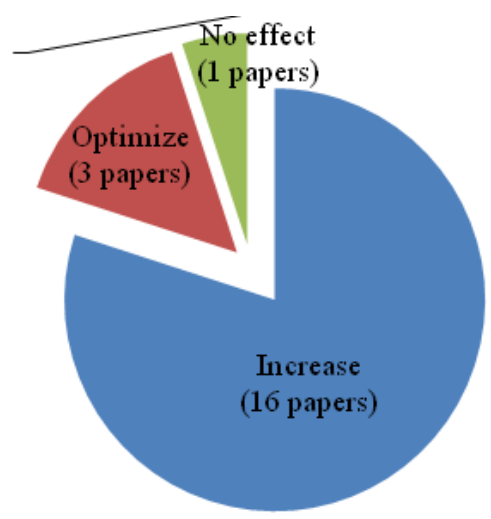

Fig. 3. Forming tool diameter journal papers

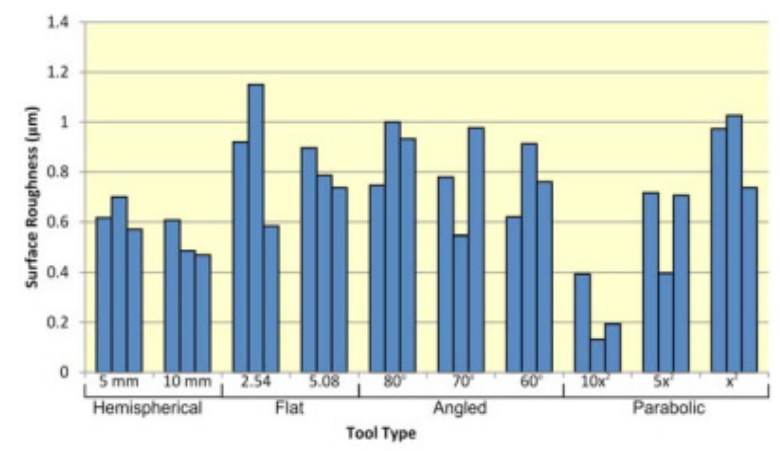

Fig. 4. Effect of various forming tool types and size on surface roughness [12] 
Table 6. Tool diameter papers summery

\begin{tabular}{|c|c|c|c|c|c|c|}
\hline $\begin{array}{l}\text { Papers: Author\& } \\
\text { reference }\end{array}$ & $\begin{array}{l}\text { Tool tip diameter } \\
(\mathrm{mm})\end{array}$ & $\begin{array}{c}\text { Tool diameter } \\
\text { level }\end{array}$ & Tool material & Blank material & $\begin{array}{l}\text { Experiment } \\
\text { replications }\end{array}$ & $\begin{array}{c}\text { Roughness } \\
\text { level }\end{array}$ \\
\hline \multicolumn{7}{|c|}{ Effect: with increase in tool diameter, roughness will decrease } \\
\hline Jeswiet [28] & $6.35,9.53,12.72$ & 1 & $\mathrm{~N} / \mathrm{A}$ & AA 5052-H32 & 3 & 2 \\
\hline Bhattacharya [29] & $4,6,8$ & 0 & $\mathrm{~N} / \mathrm{A}$ & Al 5052 & $\mathrm{~N} / \mathrm{A}$ & 2 \\
\hline Cavaler [19] & 8,10 & 0 & TiAIN coated & AISI 304L steel & 1 & 2 \\
\hline Kim [17] & $5,10,15$ & 1 & N/A & AA1050 & $\mathrm{N} / \mathrm{A}$ & 2 \\
\hline Kurra [30] & $6,10,14$ & 1 & Tool steel & EDD steel & 1 & 2 \\
\hline Radu [31] & 3,5 & 0 & Spherical tool & $\begin{array}{l}\text { DC01 Mild } \\
\text { steel }\end{array}$ & & 2 \\
\hline Shanmuganatan [32] & $2.5,5,10$ & 0 & Tool steel & AA 3003-O & $\mathrm{N} / \mathrm{A}$ & 2 \\
\hline Bagudanch [6] & 6,10 & 0 & $N / A$ & $\begin{array}{c}\text { PC, } \\
\text { PVC(TPIF) }\end{array}$ & 1 & 2 \\
\hline Rattanachan & 10,12 & 1 & $N / A$ & $\begin{array}{l}\text { DIN } 1.0037 \\
\text { steel }\end{array}$ & $\mathrm{N} / \mathrm{A}$ & 2 \\
\hline Durante [5] & $2.5,5,7.5$ & 0 & $\mathrm{~N} / \mathrm{A}$ & AA 7075-T0 & 1 & 2 \\
\hline Shanmuganatan [9] & $2.5,5,10$ & 0 & $N / A$ & AA 3003-O & 3 & 2 \\
\hline Radu [33] & 6,10 & 0 & $N / A$ & $\begin{array}{c}\text { Stainless steel } \\
304\end{array}$ & $\mathrm{~N} / \mathrm{A}$ & 2 \\
\hline Li [34] & 10,16 & 2 & $\mathrm{~N} / \mathrm{A}$ & Al 2024-T3 & $\mathrm{N} / \mathrm{A}$ & 2 \\
\hline Jagtap [35] & 8,16 & 2 & $\begin{array}{c}\text { Stainless } \\
\text { steel SS } 304\end{array}$ & Al 1050 & $\mathrm{~N} / \mathrm{A}$ & 2 \\
\hline Malwad [36] & 6,12 & 1 & HSS & AA 8011 & $\mathrm{~N} / \mathrm{A}$ & 2 \\
\hline Gulati [8] & 8,12 & 1 & HSS & Al 6063 & 3 & 2 \\
\hline \multicolumn{7}{|c|}{ Effect: Optimize tool diameter gives smaller surface roughness } \\
\hline Liu [37] & $15,20,25$ & 2 & $\mathrm{~N} / \mathrm{A}$ & AA 7075-O & 1 & 2 \\
\hline Chinnaiyan [26] & $8,10,12$ & 1 & $\begin{array}{l}\text { EN medium } \\
\text { carbon steel }\end{array}$ & Al 5052 & 3 & 2 \\
\hline Deepak [7] & $16,18,20$ & 2 & HSS & Al 2014 & 2 & 2 \\
\hline \multicolumn{7}{|c|}{ Effect: No significant effect on surface roughness } \\
\hline Bagudanch [6] & 6,10 & 0 & $\mathrm{~N} / \mathrm{A}$ & $\begin{array}{l}\text { PC, PVC } \\
\text { (SPIF) }\end{array}$ & 1 & 0 \\
\hline
\end{tabular}

Table 7. ANOVA for tool diameter

\begin{tabular}{|c|c|c|c|c|c|}
\hline Model & Sum of squares & Dof & Mean square & F & Sig. \\
\hline Between groups & 2.61 & 2 & 1.30 & 1.24 & .03 \\
\hline Within groups (error) & 1.91 & 16 & .11 & & \\
\hline Total & 4.52 & 18 & & & \\
\hline
\end{tabular}

Significance level $=\alpha=.05$

Analyze the results with the help of ANOVA in Table 7.

Factor significance Criteria:

- Factor will be Significant if $\mathrm{P}$ value $<\alpha$ $\Rightarrow .03<.05$ (Condition satisfied)

- Hence, Null Hypothesis $\left(\mathrm{H}_{\mathrm{o}}\right)$ should be rejected.

- Contribution $=(2.616 / 4.526) \times 100=57.7 \%$

It means that Alternate hypothesis (H1) should be accepted. Therefore, tool size has significant effects in terms of surface quality. It was observed that for specific step increment, increase in tool diameter, and ends between neighbors cover overlaps. Forming tool with small tip diameter focuses the strain at the area of deformation on blank sheet while tools with larger tip diameter tend to allocate strain rate over larger area of deformation. Thus larger diameter tools have considerable effect in formation process and can enhance the surface quality and reduce 
the forming time with increase in step increment without disturbing surface quality. It was observed that formability increases with smaller tool diameter. Strano et al. [38] suggested that material type and material thickness must be taking into account when choosing forming tool. Results about tool diameter and sheet thickness interaction were shown in interaction table of "tool size vs sheet thickness".

\section{Sheet material characteristics}

Various materials have been utilized in incremental sheet forming process that includes metals [39] polymer blanks [40] and others blank materials like sandwich panels [41] with high variety of surface finish. This survey does not investigate the surface finish of particular material; despite enlist them in tables for parametric analysis in order to show the comparison between different tests with same material as an example aluminum alloy (AA 3003) or poly vinyl chloride (PVC). On the base of blank material type all others forming parameters are selected.

Sheet thickness is an essential process parameter and efficiently affects the incremental sheet forming process, particularly when the forming force is required to deform the blank sheet because with increase in sheet thickness, forming forced increased [42]. For shear forming, sheet thickness is also an important factor in sine law equation in which final sheet thickness can be find with the help of initial sheet thickness and have seen accurate formed parts in single pas [43]. Equation 1. given below as

$$
\mathrm{t}_{\mathrm{f}}=\mathrm{t}_{\mathrm{i}} \times \sin (90-\varphi)
$$

Where: $t_{\mathrm{r}}=$ final sheet thickness, $t_{\mathrm{i}}=$ Initial sheet thickness, $\varphi=$ Wall angle.

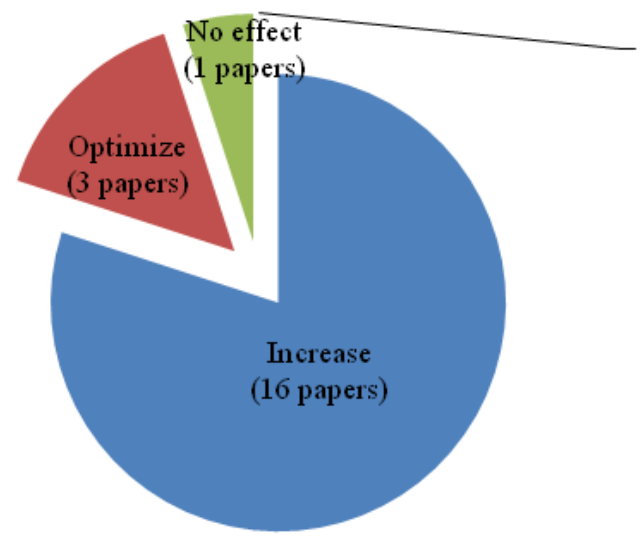

Fig. 5. Sheet thickness papers

The values of blank thickness are not essential in this survey paper because every material have different mechanical and chemical properties for example $1.5 \mathrm{~mm}$ sheet thickness of one material performs inversely to $1.5 \mathrm{~mm}$ thickness of an alternate material [39]. General influence of increasing or decreasing the sheet thickness on surface roughness has been examined.

\section{Sheet thickness}

In this survey paper, few papers were seen that showed the effect of sheet thickness on surface roughness. Total 5 journal papers varied sheet thickness to decide their impact on surface roughness. Only one papers showed that with increase in sheet thickness, surface roughness increased. 2 papers showed that with decease in sheet thickness, surface roughness decreased. 2 papers suggested that an optimized sheet thickness improved surface finish. Summery of papers is given in the Table 8 . Analyze the results with the help of ANOVA in Table 9.

Table 8. Sheet thickness papers summery

\begin{tabular}{|c|c|c|c|c|c|}
\hline $\begin{array}{c}\text { Papers: Author\& } \\
\text { reference }\end{array}$ & Sheet material & Sheet thickness (mm) & $\begin{array}{c}\text { Sheet thickness } \\
\text { levels }\end{array}$ & $\begin{array}{c}\text { Experiment } \\
\text { replications }\end{array}$ & $\begin{array}{c}\text { Roughness } \\
\text { level }\end{array}$ \\
\hline \multicolumn{7}{|c|}{ Effect: with decrease in sheet thickness, roughness decreased. } \\
\hline Gulati [8] & Al 6063 & $.55,1.09,1.67$ & 2 & 3 & 1 \\
\hline $\begin{array}{c}\text { Shanmuganatan } \\
\text { [9] }\end{array}$ & AA 3003-O & $1,1.25$ & 1 & 3 & 1 \\
\hline \multicolumn{7}{|c|}{2} & 2 & 2 \\
\hline Deepak [7] & Al 2014 & $1.2,2,2.3$ & 2 & 2 \\
\hline \multicolumn{7}{|c|}{ Effect: Optimize sheet thickness, decreased surface roughness } \\
\hline Liu [37] & AA 7075-O & $1.02,1.60,2.54$ & 2 & 1 & 2 \\
\hline Chinnaiyan [26] & Al 5052 & $.8,1,1.2$ & 1 & 3 & 2 \\
\hline
\end{tabular}


Table 9. ANOVA for sheet thickness

\begin{tabular}{|c|c|c|c|c|c|}
\hline Model & Sum of squares & dof & Mean square & F & Sig. \\
\hline Between Groups & .05 & 1 & .05 & .20 & .68 \\
\hline Within Groups (error) & .75 & 3 & .25 & & \\
\hline Total & .80 & 4 & & & \\
\hline
\end{tabular}

\section{Factor significance Criteria:}

- Factor will be Significant if $\mathrm{P}$ value $<\alpha$ $\Rightarrow .68>.05$ (Condition not satisfied).

- Hence, Null Hypothesis $\left(\mathrm{H}_{\mathrm{o}}\right)$ should be accepted.

- Contribution $=(.050 / .800) \times 100=6.25 \%$.

It means that Alternate hypothesis $\left(\mathrm{H}_{1}\right)$ should be rejected. Therefore, sheet thickness has insignificant effect on surface roughness. From this survey it was observed that surface quality decreases as sheet thickness increases.

Deepak examined different sheet thickness of AL 2014 with two replications of each experiment in order to get better results on surface quality. They analyzed that with increase in sheet thickness roughnss increased [7].

On the other side, Shanmuganatan et al. tested aluminim alloy (AA 3003-O) with different sheet thickness and investigated that with decrease in sheet thickness surface roughness decreased [9]. It might be due to that more forming force is required for thick sheets as compared to thin sheets in order to metal flow thus rough surface seen for thick sheets.

\section{Step increment}

In this survey paper, 27 differerent papres were seen that varied step increment in order to decide their effect on surface qulaity. Out of these, 19 of the papers presents that surface quality of material improved by decreasing the step down. 3 papers suggested that with increasing the step increment surface roughness decreased. 2 papers showed that an optimization of step increment decreased surface roughness. 3 papers presented that step down has insignificant effect on surface roughness. Summery of papers about step down is explained in Table 10.

Summery of papers is given in the Table 10 . Analyze the results with the help of ANOVA shown Table 11.

\section{Factor significance Criteria:}

- Factor will be Significant if $\mathrm{P}$ value $<\alpha$ $\Rightarrow .045<.05$ (Condition satisfied)

- Hence, Null Hypothesis (Ho) should be rejected.

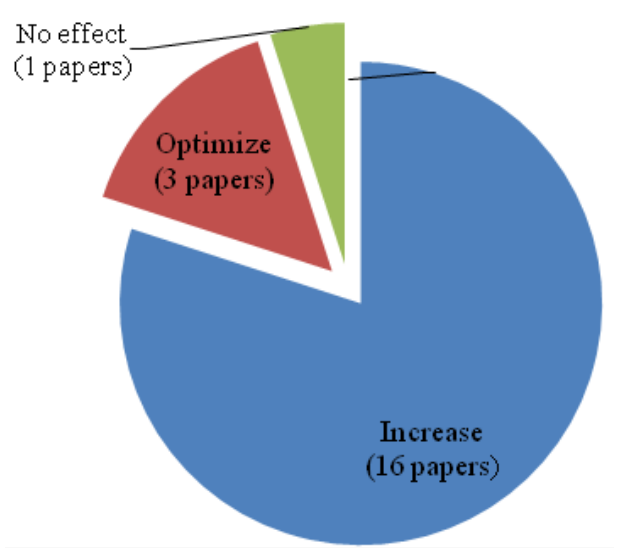

Fig. 6. Step increment papers

- Contribution $=(4.935 / 13.181) \times 100=19.9$ $\%=37.4 \%$

It means that Alternate hypothesis $\left(\mathrm{H}_{1}\right)$ should be accepted. Therefore, step increment has significant effect on roughness. Figure 7 shows the effect of step increment on surface roughness. As, with increase in step increment surface roughness decreased. It might be important in some cases, to optimize surface roughness and forming process speed in which surface quality shoud be improved per milimeter, it would require to be evaluated. An optimized value of step increment in necessary when tradeoff between surface quality and forming time is required.

Hagan tested different step increment for aluminum alloy (AA 3003) with one replication of each experiment. They found that with decrease in step increment surface roughness decreased [44]. Bhattacharya et al. [29] tested different step increment on aluminum (Al 5052). They examined that with increasing the step increment surface roughness increased first up to certain value, after this surface roughness decreased with increase in step depth.

Assumptions related to the effect of step increment on surface roughness were proposed by various papers in this survey. With decresing step down has been appeared to increase surface finish and have significant effect on forming time. It might be important in some cases, to optimize sur- 
Table 10. Step increment papers summery

\begin{tabular}{|c|c|c|c|c|c|}
\hline $\begin{array}{c}\text { Papers: Author\& } \\
\text { reference }\end{array}$ & Sheet material & Step increment $(\mathrm{mm})$ & $\begin{array}{c}\text { Step increment } \\
\text { levels }\end{array}$ & $\begin{array}{l}\text { Experiment } \\
\text { replications }\end{array}$ & $\begin{array}{c}\text { Roughness } \\
\text { levels }\end{array}$ \\
\hline \multicolumn{6}{|c|}{ Effect: With decrease in step increment, roughness decreased } \\
\hline Hagan $[44]$ & Al 3003 & $.5,1,1.5$ & 2 & 1 & 1 \\
\hline Bhattacharya [29] & Al 5052 & $.2, .6,1$ & 2 & $\mathrm{~N} / \mathrm{A}$ & 1 \\
\hline Attanasio [45] & Fe P04 steel & $.2, .5,1$ & 2 & $\mathrm{~N} / \mathrm{A}$ & 1 \\
\hline Desai $[46]$ & Al1200-H14 & $.2, .3, .4, .5, .6, .7, .8$ & 1 & 3 & 1 \\
\hline Radu [31] & DC01 Mild steel & $.05, .5$ & 1 & $\mathrm{~N} / \mathrm{A}$ & 1 \\
\hline Patel [47] & IS 19000 (Al alloy) & $.1, .2, .3$ & 0 & 1 & \\
\hline Bagudanch [6] & PC,PVC(SPIF) & $.2, .5$ & 1 & 2 & 1 \\
\hline Kurra [30] & EDD steel & $.7,1.1,1.5$ & 2 & 1 & 1 \\
\hline Gulati [8] & Al 6063 & $.5,1,1.5$ & 2 & 3 & \\
\hline Radu [33] & Stainless steel & $.05, .5$ & 1 & $\mathrm{~N} / \mathrm{A}$ & 1 \\
\hline Khazaali [48] & SS 304 & $1,1.5,2$ & 2 & $\mathrm{~N} / \mathrm{A}$ & 1 \\
\hline $\begin{array}{c}\text { Shanmuganatan } \\
{[32]}\end{array}$ & AA 3003-O & $.2, .4, .6, .8$ & 1 & N/A & 1 \\
\hline Uttarwar [49] & Al 1100 & $.2, .5,1$ & 2 & 1 & 1 \\
\hline Mulay [50] & AA 8011 & $.2, .5, .1$ & 1 & $\mathrm{~N} / \mathrm{A}$ & 1 \\
\hline Durante [5] & AA 7075-TO & $.2, .4, .6$ & 1 & $\mathrm{~N} / \mathrm{A}$ & 1 \\
\hline Lu [51] & Al 7075-O & $.1, .6,1.1$ & 2 & $\mathrm{~N} / \mathrm{A}$ & 1 \\
\hline Lasunon [52] & AA 5052 & $.38, .76$ & 1 & $\mathrm{~N} / \mathrm{A}$ & 1 \\
\hline Malwad [36] & AA 8011 & $.2, .5$ & 1 & $\mathrm{~N} / \mathrm{A}$ & 1 \\
\hline Jagtap [35] & Al 1050 & $.5,1$ & 2 & $\mathrm{~N} / \mathrm{A}$ & 1 \\
\hline \multicolumn{6}{|c|}{ Effect: With increase in step increment, roughness decreased } \\
\hline Cavaler [19] & AISI 304L steel & $.4, .6, .8$ & 1 & 1 & 2 \\
\hline Rattanachan [53] & DIN 1.0037 steel & 1,2 & 2 & $\mathrm{~N} / \mathrm{A}$ & 2 \\
\hline Bagudanch [6] & PC, PVC(TPIF) & $.2, .5$ & 1 & 2 & 2 \\
\hline \multicolumn{6}{|c|}{ Effect: No significant effect of step increment on roughness } \\
\hline Bermudez I [54] & Al $1100-\mathrm{H} 0$ & $.5,1$ & 2 & 3 & 0 \\
\hline Yazar [27] & QD steel & $.2, .5, .8$ & 1 & 3 & 0 \\
\hline Deepak [7] & Al 2014 & $.3, .5, .75$ & 1 & 2 & 0 \\
\hline \multicolumn{6}{|c|}{ Effect: Optimize step increment, will minimum surface roughness } \\
\hline Liu [37] & AA 7075-O & $.2, .5, .8$ & 1 & 1 & 2 \\
\hline Mugendiran [55] & AA 5052 & $.25, .5, .75$ & 1 & 1 & 2 \\
\hline
\end{tabular}

Table 11. ANOVA for step increment

\begin{tabular}{|c|c|c|c|c|c|}
\hline Model & Sum of Squares & Df & Mean Square & F & Sig. \\
\hline Between Groups & 4.93 & 2 & 2.46 & 3.401 & .045 \\
\hline Within Groups(error) & 8.24 & 16 & .63 & & \\
\hline Total & 13.18 & 18 & & & \\
\hline
\end{tabular}

face quality and forming process speed in which surface quality should be improved per millimeter. For example, would require to be evaluated.

\section{Feed Rate}

In this survey paper, 18 journal papers have been found that showed the effect of feed rate on surface quality. Out of these, 6 journal papers claimed that surface roughness would be decrased with decrease in feed rate. 4 papers found that with increase in feed rate, roughness decreased. 3 papers suggested that an optimized value of feed rate minimized the surface roughness. 5 papers claimd that feed rate has no impact on surface roughness. Summery of papers about feed rate is explained in Table 12. 


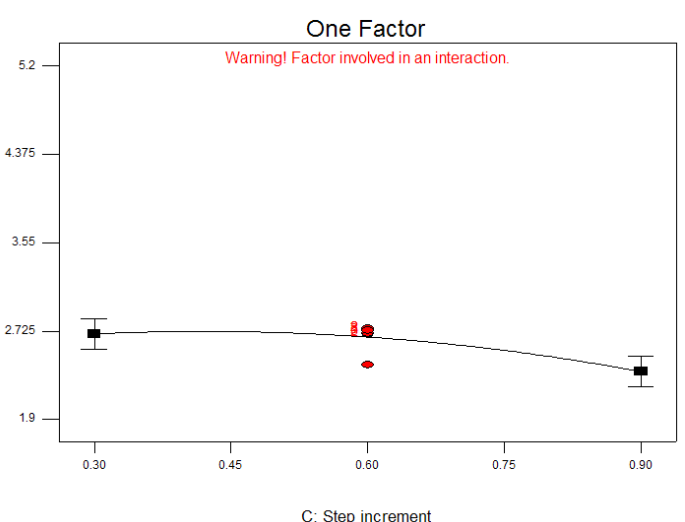

Fig. 7. Effect of step increment on surface roughness

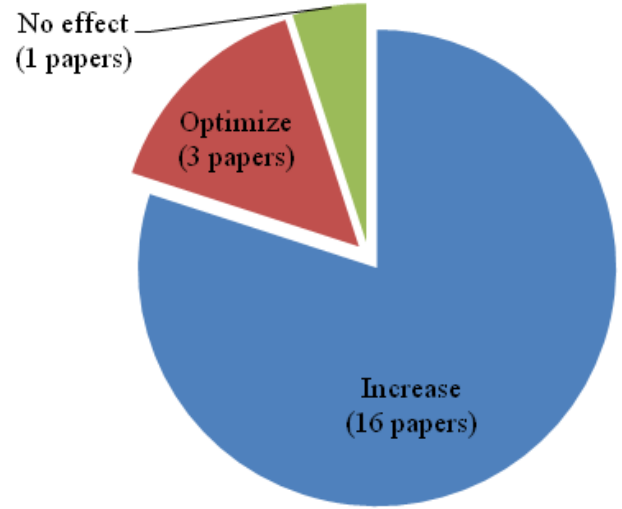

Fig. 8. Feed rate papers

Table 12. Feed rate papers summery

\begin{tabular}{|c|c|c|c|c|c|}
\hline Papers: Author\& reference & Sheet material & Feed rate $(\mathrm{mm} / \mathrm{min})$ & $\begin{array}{l}\text { Feed rate } \\
\text { levels }\end{array}$ & $\begin{array}{l}\text { Experiment } \\
\text { replications }\end{array}$ & $\begin{array}{c}\text { Surface roughness } \\
\text { levels }\end{array}$ \\
\hline \multicolumn{6}{|c|}{ Effect: with decrease in feed rate, Surface roughness will decrease } \\
\hline Patel [47] & $\begin{array}{l}\text { IS } 19000 \\
\text { (Al alloy) }\end{array}$ & $1000,1500,2000$ & 1 & 1 & 1 \\
\hline Mulay [50] & AA 8011 & $500,800, \quad 1200$ & 0 & $\mathrm{~N} / \mathrm{A}$ & 1 \\
\hline Rattanachan [53] & $\begin{array}{l}\text { DIN } 1.0037 \\
\text { steel }\end{array}$ & $3142, \quad 3770$ & 2 & $\mathrm{~N} / \mathrm{A}$ & 1 \\
\hline Chinnaiyan [26] & AA 5052 & $300,600, \quad 900$ & 0 & 3 & 1 \\
\hline Gulati [8] & Al 6063 & $1000,2000,2500$ & 2 & 3 & 1 \\
\hline \multicolumn{6}{|c|}{ Effect: with increase in feed rate, surface roughness will decrease } \\
\hline Silva [56] & SAE 1008 steel & $\begin{array}{c}720,1440,1800, \\
2160,4800,8400\end{array}$ & 1 & 1 & 2 \\
\hline Bermudez [54] & Al $1100-\mathrm{H} 0$ & $2000, \quad 3500$ & 2 & 3 & 2 \\
\hline Yazar [27] & QD steel & $900,1200,1500$ & 1 & 3 & 2 \\
\hline Radu [33] & Stainless 304 & $1500, \quad 3000$ & 2 & $\mathrm{~N} / \mathrm{A}$ & 2 \\
\hline \multicolumn{6}{|c|}{ Effect: Optimize feed rate for minimum surface roughness } \\
\hline Deepak [7] & Al 2014 & $1500,2000,3000$ & 2 & 2 & 2 \\
\hline Mugendiran [55] & AA 5052 & $500, \quad 650, \quad 800$ & 0 & 1 & 2 \\
\hline Kurra [30] & EDD Steel & $750, \quad 1500, \quad 2250$ & 1 & 1 & 2 \\
\hline \multicolumn{6}{|c|}{ Effect: Feed rate has no significant effect on surface roughness } \\
\hline Liu [37] & AA 7075-O & $4000,5000,6000$ & 2 & 1 & 0 \\
\hline Bagudanch [6] & PC, PVC & $1500, \quad 3000$ & 2 & 1 & 0 \\
\hline Uttarwar [49] & Al 1100 & $500,800, \quad 1200$ & 0 & 1 & 0 \\
\hline Shah [57] & Al 1100 & $500,800, \quad 1200$ & 0 & 1 & 0 \\
\hline Lasunon [52] & AA 5052 & $317, \quad 635, \quad 1270$ & 1 & $\mathrm{~N} / \mathrm{A}$ & 0 \\
\hline
\end{tabular}

Table 13. ANOVA for feed rate

\begin{tabular}{|c|c|c|c|c|c|}
\hline Model & Sum of squares & dof & Mean square & F & Sig. \\
\hline Between Groups & .19 & 2 & .09 & .687 & .52 \\
\hline Within Groups (error) & 1.52 & 11 & .13 & & \\
\hline Total & 1.71 & 13 & & & \\
\hline
\end{tabular}

Summery of papers is given in the Table 12. Analyze the results with the help of ANOVA shown in Table 13. 


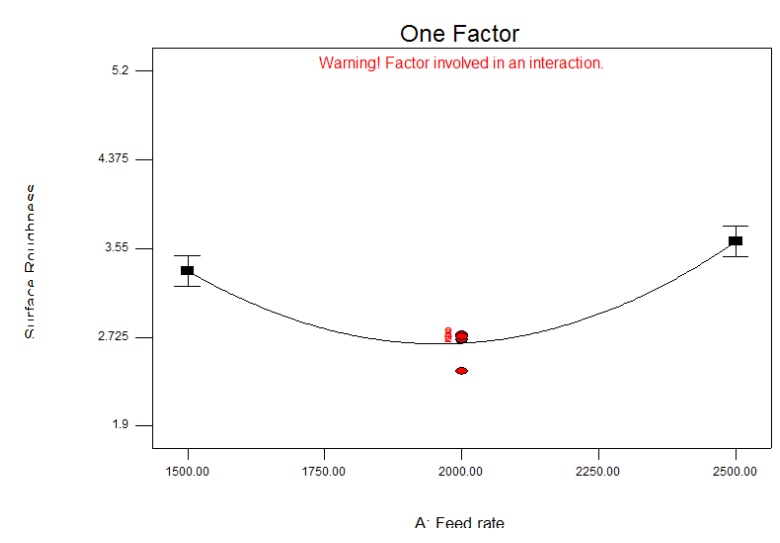

Fig. 9. Effect of feed rate on surface roughness

\section{Factor significance Criteria:}

- Factor will be Significant if $\mathrm{P}$ value $<\alpha$ $\Rightarrow .52>.05$ (Condition not satisfied)

- Hence, Null Hypothesis (Ho) should be accepted.

- Contribution $=(.190 / 1.714) \times 100=11 \%$

It means that Alternate hypothesis $\left(\mathrm{H}_{1}\right)$ should be rejected. Therefore, feed rate has insignificant effect on surface roughness. Figure 8 shows the effect of feed rate on surface roughness. As, with increase in feed rate surface roughness decreased at some extent the surface roughness increased. Chinnaiyan investigated aluminum alloy (AA 5052) sheet metal under different feed rate 300 , 600 and $900 \mathrm{~mm} / \mathrm{rev}$ with 3 replications of each experimnet. They suggested that with decrease in feed rate surface roughnedd decreased. Moreover smaller feed rate inceased forming time [26].

Gulati tested alminum ( $\mathrm{Al}$ 6063) blank material at three different level of feed rate with three rpelictaion of each experiment using Design of experiment (DOE). They found that with decrease in feed rate surface roughness decreased [8].

Yazar performed experiments on quartz (QD) steel at different level of feed rate 900,1200 and 1500 $\mathrm{mm} / \mathrm{rev}$ with three replications of each experiment using orthogonal array. They suggested that with increase in feed rate surface roughness decreased [27].

It can be seen that impact of feed rate relies upon sheet material that formed in incremental sheet forming. Feed rates combined with step increment effects the forming time. However, for the trade off between surface roughness and forming time. Optimization would be required between these forming process parameters. Information about the imapct of feed rates on various materials would be necessary for the improvement of surface quality as feed rate deceased.

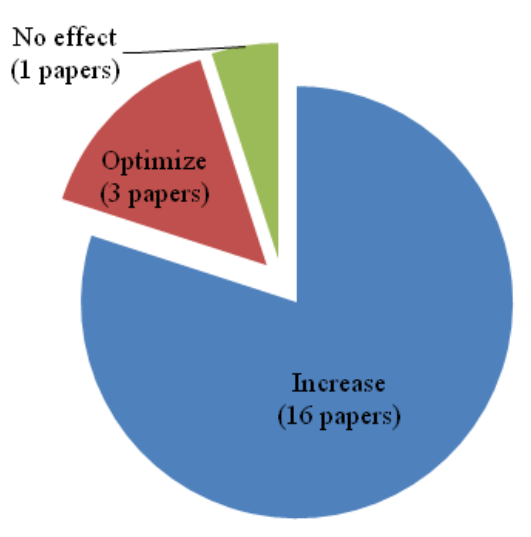

Fig. 10. Spindle rotational speed papers

\section{Spindle rotational speed}

In this survay, 15 journals papers presented the impact of spindle speed on surface roughness. Out of these, 5 papers claimed that surface rughness decreased with increase in spindle speed. 3 papers suggested that with decrease in spindle speed surface roughness decreased. 4 papers represents that an optimized spindle speed would cause to decrease surface roughness. 3 papers suggested that rotational speed has no effect on surface roughness. Summery of papers about spindle rotational speed is explained in Table 14.

Summery of papers is given in the Table 14 .

Analyze the results with the help of ANOVA shown in Table 15.

\section{Factor significance Criteria:}

- Factor will be Significant if $\mathrm{P}$ value $<\alpha$ $\Rightarrow .10>.05$ (Condition not satisfied)

- Hence, Null Hypothesis (Ho) should be accepted.

- Contribution $=(1.571 / 6.0) \times 100=26 \%$

It means that Alternate hypothesis $\left(\mathrm{H}_{1}\right)$ should be rejected. Therefore, spindle speed has insignificant effect on surface roughness. Figure 10 shows the effect of spindle speed on surface roughness. As, with increase in spindle speed surface roughness decreased. Desai tested aluminum (Al 1200-H14) sheet blank at constant feed and step increment and varying spindle rotational speed and investigated their effect on surface roughness [46].

Bermudez et al. [54] developed design of experiments in order to investigate the effect of spindle rotation speed on surface roughness. They tested aluminum (Al 1100-H0) at 0 and $500 \mathrm{rev} /$ min with three replication of each of each experiment. They found that spindle rotational sped in- 
Table 14. Spindle rotational speed papers summery

\begin{tabular}{|c|c|c|c|c|c|}
\hline $\begin{array}{l}\text { Papers: Author\& } \\
\text { reference }\end{array}$ & Sheet material & Spindle speed (rpm) & $\begin{array}{l}\text { Spindle } \\
\text { speed } \\
\text { levels }\end{array}$ & $\begin{array}{l}\text { Experiment } \\
\text { replications }\end{array}$ & $\begin{array}{l}\text { Surface } \\
\text { roughness } \\
\text { levels }\end{array}$ \\
\hline \multicolumn{6}{|c|}{ Effect: with decrease in Spindle speed, Surface roughness decreased } \\
\hline Hagan [44] & Al 3003 & $500,1000,1500,2000,2500$ & 1 & 1 & 1 \\
\hline Bermudez [54] & Al $1100-\mathrm{H} 0$ & 0,1500 & 0 & 3 & 1 \\
\hline Rattanachan [58] & DIN 1.0037 steel & 100,1000 & 0 & $\mathrm{~N} / \mathrm{A}$ & 1 \\
\hline \multicolumn{6}{|c|}{ Effect: with increase in spindle speed, Surface roughness decreased } \\
\hline Desai [46] & Al1200-H14 & $500,750,1000,1250$ & 0 & 1 & 2 \\
\hline Radu [33] & $\begin{array}{c}\text { Stainless steel } \\
304\end{array}$ & 500,1000 & 0 & $\mathrm{~N} / \mathrm{A}$ & 2 \\
\hline Mulay [50] & AA 8011 & $600,800,1000$ & 0 & $\mathrm{~N} / \mathrm{A}$ & 2 \\
\hline Radu [31] & DC01 Mild steel & 500,1000 & 0 & $\mathrm{~N} / \mathrm{A}$ & 2 \\
\hline Patel [47] & IS 19000 (Al alloy) & $500,1000,1500$ & 0 & 1 & 2 \\
\hline \multicolumn{6}{|c|}{ Effect: Significant effect of spindle speed on surface roughness } \\
\hline Petek [59] & DC05 steel & 0,4000 & 1 & 3 & 2 \\
\hline Uttarwar [49] & Al 1100 & $600,800,1000$ & 0 & 1 & 2 \\
\hline Shah [57] & Al 1100 & $600,800,1000$ & 0 & 1 & 2 \\
\hline \multicolumn{6}{|c|}{ Effect: Optimize spindle speed to minimize roughness } \\
\hline Gulati [8] & Al 6063 & $0,250,500$ & 0 & 3 & 0 \\
\hline Chinnaiyan [26] & Al 5052 & $300,450,600$ & 0 & 3 & 0 \\
\hline Deepak [7] & Al 2014 & $0,100,200$ & 0 & 2 & 0 \\
\hline Mugendiran [55] & AA 5052 & $1500,2000,2500$ & 1 & 1 & 0 \\
\hline
\end{tabular}

Table 15. ANOVA for spindle speed

\begin{tabular}{|c|c|c|c|c|c|}
\hline Model & Sum of squares & dof & Mean square & F & Sig. \\
\hline Between Groups & 1.57 & 1 & 1.57 & 3.19 & .10 \\
\hline Within Groups (error) & 4.42 & 9 & .49 & & \\
\hline Total & 6.00 & 10 & & & \\
\hline
\end{tabular}

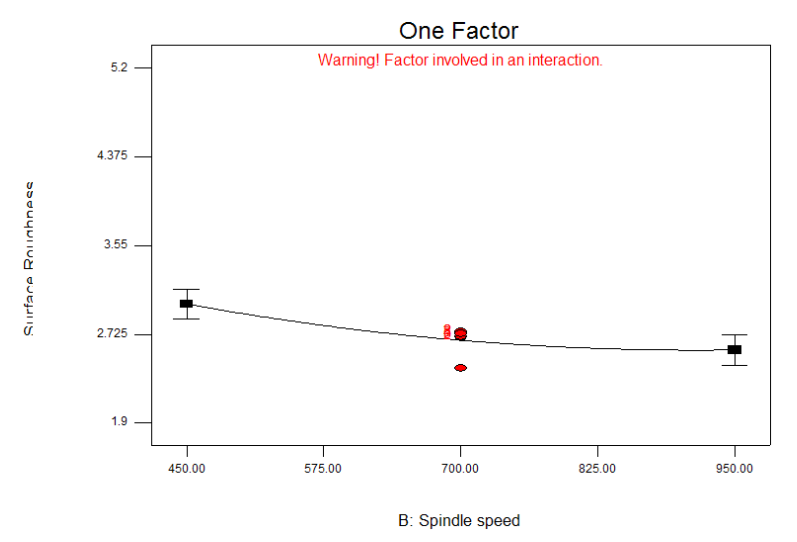

Fig. 11. Effect of spindle speed on surface roughness

fluence the surface roughness $n$ both perpendicular and parallel direction. They suggested that with decrease in spindle speed surface roughness decreased.
In view of these results from 15 papers, it appears to be evident that with increasing the rotational speed over $0 \mathrm{rpm}$ will probably bring the improvement in surface quality. Two optimized paper [60] [61] upper limit will be discovered when contact between metal sheet and tool is too high and surface fracture began. These papers shows that there would be no example where stationary forming tool should be utilized. With the help ball end tool, minimum friction was seen. Rigid stationary forming tools are inconvenient to both surface finish and formability, shown in T. Hakutani et al. [61] and Xu et al. [62] and Durante et al. [5].

\section{Direction of Spindle rotation}

Just two papers in this survey attempted research utilizing conventional and vertical milling direction. Obikawa et al. [61] combined this view 
point into their tests on alumimium foils. Spindle speed range of 0 to $25000 \mathrm{rpm}$ was examined in both vertical and conventional milling directions, indicated by $-25000 \mathrm{rpm}$ to $+25000 \mathrm{rpm}$. At high rotational speeds, there was small change change observed between these two rotational directions.

Durante et al. [5] step by step formed the parts with rigid hemispherical tool rotationing in both directions clockwise and anti clock wise, and matched the reults of those rolling ball tool and stationary rigid tool. Spindle rotation direction have not significant impact on formability but have significant effect on forming forces and on surface quality. The rigid hemispherical tool created an poorer surface quality as compred to the rolling ball tool. Solid hemispherical tool rotating at $600 \mathrm{rpm}$ in rolling direction in order to produce miminal forming force.

The conclusion that was extract from the results of this portion and in the last section of spindle speed is that for most of the materials forming tools should be revolved at high speeds in order to maximize the formability of forming parts and minimize surface roughness. All discussion considerd that rotational direction of spindle will not effect the results of any importance. However climb will at present remain most widely recognized milling mode as forming tools rolling on the forming sheet in order to minimize the relative friction. Furthermore, it could be claimed there would be no condition where tradational milling would be useful.

\section{FACTORS INTERACTION EFFECT ON SURFACE ROUGHNESS}

The following portion in this survey demonstrated the important factors interactions and discuss about their importance on response.

\section{Spindle rotational speed and feed rate interaction}

Spindle speed and feed rate play a significant role in friction between formed tool and sheet accompanying heat generated during incremental
Table 16. Spindle rotational speed and feed rate interaction

\begin{tabular}{|c|c|c|c|}
\hline $\begin{array}{l}\text { Papers: } \\
\text { Author\& } \\
\text { reference }\end{array}$ & $\begin{array}{l}\text { Feed rate } \\
(\mathrm{mm} / \mathrm{min})\end{array}$ & $\begin{array}{c}\text { Spindle } \\
\text { speed (rpm) }\end{array}$ & $\begin{array}{l}\text { Sheet } \\
\text { material }\end{array}$ \\
\hline \multicolumn{4}{|c|}{$\begin{array}{l}\text { Effect: Feed rate is regular, when spindle speed in- } \\
\text { creases, Roughness will be lower and vice versa }\end{array}$} \\
\hline Pengtao [21] & Constant & $\begin{array}{l}50,150,250 \\
350, \ldots ., 950\end{array}$ & 2A112 \\
\hline $\begin{array}{l}\text { Mugendiran } \\
{[55]}\end{array}$ & Constant & $\begin{array}{l}1500,2000 \\
2500\end{array}$ & AA 5052 \\
\hline \multicolumn{4}{|c|}{$\begin{array}{l}\text { Effect: spindle speed is regular, when feed rate de- } \\
\text { creases, Roughness will be lower and vice versa }\end{array}$} \\
\hline Pengtao [21] & $\begin{array}{c}100, \quad 200 \\
300, \ldots \ldots, 1000\end{array}$ & Constant & $2 \mathrm{~A} 112$ \\
\hline $\begin{array}{l}\text { Mugendiran } \\
{[55]}\end{array}$ & $500,650,800$ & Constant & AA 5052 \\
\hline \multicolumn{4}{|c|}{$\begin{array}{l}\text { Effect: Reducing feed rate and spindle speed will } \\
\text { decrease surface roughness }\end{array}$} \\
\hline $\begin{array}{l}\text { Rattanachan } \\
{[53]}\end{array}$ & 3142,3770 & 100,200 & $\begin{array}{c}\text { DIN } \\
1.0037\end{array}$ \\
\hline \multicolumn{4}{|c|}{$\begin{array}{c}\text { Optimize: Spindle speed and feed gives lower surface } \\
\text { roughness }\end{array}$} \\
\hline $\begin{array}{l}\text { Bermudez } \\
\quad[54]\end{array}$ & 2000,3500 & 0,1500 & $\begin{array}{l}\text { Al } 1100- \\
\text { HO }\end{array}$ \\
\hline $\begin{array}{l}\text { Chinnaiyan } \\
{[26]}\end{array}$ & $300,600,900$ & $\begin{array}{l}300,450 \\
\quad 600\end{array}$ & Al 5052 \\
\hline \multicolumn{4}{|c|}{$\begin{array}{c}\text { Effect: No significant effect of feed and speed on } \\
\text { surface roughness }\end{array}$} \\
\hline Uttarwar [49] & $\begin{array}{l}500,800 \\
1200\end{array}$ & $\begin{array}{l}600,800 \\
1000\end{array}$ & Al 1100 \\
\hline
\end{tabular}

sheet forming process. Two papers were seen that showed that the interaction between these two forming process parameters, both papers utilized Polymers in their experiments. Bermudez et al. [54] and Chinnaiyan et al. [26] demonstrated that idecreased roughness for specific interaction of spindle speed and feed rate, result the high interaction between these two parameters using Aluminium alloy.

Summery of papers is given in the Table 16 .

Bagudanch et al. [6] found no effect of speed and feed interaction on formability, however showed a critical results on surface quality. They utilized comparative feed rates such as $1500 \mathrm{~mm} /$ $\mathrm{min}$ and $3000 \mathrm{~mm} / \mathrm{min}$ and diverse values of spindle speed free rotation mean $0 \mathrm{rpm}$ and 2000 $\mathrm{rpm}$. Free rotation of forming tool would have

Table 17. ANOVA for Spindle rotational speed and feed rate interaction

\begin{tabular}{|c|c|c|c|c|}
\hline Model & Sum of squares & dof & Mean square & F \\
\hline Between Groups & .75 & 1 & .75 & 2.40 \\
\hline Within Groups (error) & 1.25 & 4 & .31 & \\
\hline Total & 2.00 & 5 & & \\
\hline
\end{tabular}




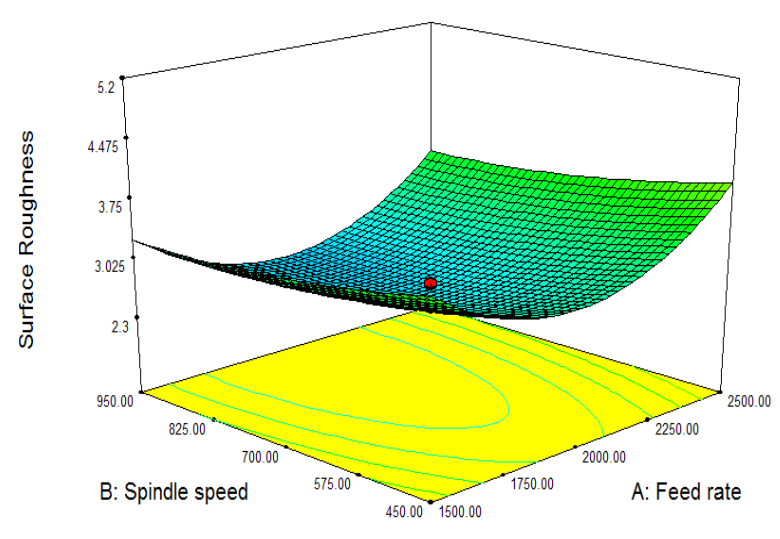

Fig. 12. Effect of spindle rotational speed and feed rate interaction on surface roughness

caused low spindle speed of $50 \mathrm{rpm}$ to $160 \mathrm{rpm}$. Thus, it would be motivating to chek a central point spindle speed to look at with results comes from Le et al. [40].

Analyze the results with the help of ANOVA in Table 17.

\section{Factor significance Criteria:}

- Factor will be Significant if $\mathrm{P}$ value $<\alpha$ $\Rightarrow .045<.05$ (Condition satisfied)

- Hence, Null Hypothesis ( $\left.\mathrm{H}_{0}\right)$ should be rejected.

- Contribution $=(.750 / .20) \times 100=37.5 \%$

It means that Alternate hypothesis $\left(\mathrm{H}_{1}\right)$ should be accepted. Therefore, spindle speed and feed rate interactions have significant effect on roughness. Figure 12 shows that spindle speed and feed rate interaction effects on surface roughness. As, spindle speed and feed rate increase surface roughness decreased at some extent after this surface roughness increased. There is an opportunity for understanding the impact of this interaction on materials others than polymers, in order to overcome frictional condition. Furthermore, build up an upper and lower operating border of the relation of feed rate and spindle speed.

\section{Tool diameter and sheet thickness interaction}

In this section an interaction between forming tool diameter and blank thickness discussed. There is an indication to demonstrate that interaction of tool tip diameter and sheet thickness plays an important role in surface roughness of any type of material, regardless whether part will form or not. A smaller tool tip diameter with a thick sheet can damage the surface, unless the part will become useless [63]. Table 18 illustrates extra data for the papers mention above in the table of tool size. In the table ratio $\min \mathrm{R} / \mathrm{t} *$ and $\max \mathrm{R} / \mathrm{t} *$ has no unit because tool radius and sheet thickness has same unit (mm). The difference between $\max R / t$ and $\min R / t$ is persented as range in the Table 18.

Summery of papers is given in the Table 18 . Analyze the results with the help of ANOVA in Table 19.

\section{Factor significance Criteria:}

- Factor will be Significant if P value $<\alpha$ $\Rightarrow .08>.05$ (Condition not satisfied)

- Hence, Null Hypothesis ( $\left.\mathrm{H}_{0}\right)$ should be rejected.

- Contribution $=(.097 / .897) \times 100=11 \%$

Table 18. Paper summery

\begin{tabular}{|c|c|c|c|c|c|}
\hline $\begin{array}{l}\text { Papers: Author\& } \\
\text { reference }\end{array}$ & $\min R / t^{*}$ & $\max R / t^{*}$ & Range & Sheet material & Sheet thickness (mm) \\
\hline \multicolumn{6}{|c|}{ Effect: with increase in tool diameter, surface roughness will decrease } \\
\hline Cavaler et al. [19] & 8 & 10 & 2 & AISI 304L & .5 \\
\hline Bagudanch et al.[6] & 2 & 3.34 & 1.34 & PC, PVC & 1.5 \\
\hline Li [34] & 5 & 8 & 3 & Al 2024-T3 & 1 \\
\hline Shanmuganatan [32] & 1 & 5 & 4 & AA 3003-O & $1, \quad 1.25$ \\
\hline Durante et al. [5] & 2.5 & 7.5 & 5 & AA 7075-T0 & 1 \\
\hline Shanmuganatan [9] & 1 & 5 & 4 & AA 3003-O & $1, \quad 1.25$ \\
\hline \multicolumn{6}{|c|}{ Effect: with decrease in tool diameter, surface roughness will decrease } \\
\hline Gulati et al. [8] & 2.39 & 10.90 & 8.51 & Al 6063 & $.55, \quad 1.09, \quad 1.67$ \\
\hline \multicolumn{6}{|c|}{ Effect: Optimize tool diameter will decrease surface roughness } \\
\hline Liu et al. [37] & 2.95 & 12.25 & 9.30 & AA 7075-O & $1.02, \quad 1.60, \quad 2.54$ \\
\hline Chinnaiyan et al. [26] & 3.33 & 7.5 & 4.16 & AI 5052 & $.8, \quad 1, \quad 1.2$ \\
\hline Deepak et al. [7] & 3.47 & 8.33 & 4.86 & Al 2014 & $1.2, \quad 2$ \\
\hline
\end{tabular}

*Range $=$ Max tool radius/sheet thickness-Min too radius/sheet thickness 
Table 19. ANOVA for Tool size and sheet thickness interaction

\begin{tabular}{|c|c|c|c|c|c|}
\hline Model & Sum of squares & dof & Mean square & F & Sig. \\
\hline Between Groups & .09 & 2 & .04 & .14 & .08 \\
\hline Within Groups (error) & .80 & 4 & .20 & & \\
\hline Total & .89 & 6 & & & \\
\hline
\end{tabular}

It means that Alternate hypothesis $\left(\mathrm{H}_{1}\right)$ should be accepted. Therefore, Tool size and sheet thickness interaction has insignificant effect on surface roughness. Bagudanch et al. [64] conducted analysis of variance (ANOVA) with full factorial and discovered that tha interaction between tool diameter and sheet thickness was uneffected on formability however, have significant effect on surface quality. Manco et al. [65] carried analysis of variance (ANOVA) and discovered that interaction being reffered to did not significantly affect the mimimum sheet metal thickness shown in tests.

It means that In order to understand this interaction would permit the forming tool to be selected based on specific material and sheet metal thickness, in the situation where the last is product requirment. As Silva et al. [66] focus on that it is substantially more reasonable to change sheet thickness over a large range of forming tool size.

\section{Sheet thickness and step down interaction}

Bagudanch et al. [64] and Ham et al. [14] both surveyed sheet thickness and step down interaction with the help of analysis of variance (ANOVA) observed that this interaction has insignificant effect on response.
A medium impact of sheet thickness and step increment was seen by Manco et al. [65] and Hussain et al. [63] observed that this interaction has insgnificant effect on fracture modes examined in their paper.

Step down and sheet material thickness interaction effect is consequently not vast. So, more research would required to find in view of if there is an optimal choice of sheet thickness and step increment.

\section{PARAMETERS COMPARISON ON SURFACE ROUGHNESS}

Bar graph shown below in Figure 8 analyzes the total amount of papers that were found for every process parameter in this survey paper. Step increment had highest number of papers, followed by tool tip diameter and feed rate. Few papers were found about spindle rotation speed, sheet thickness and forming tool types. There are some possible causes for limited research in this direction. The factors could have smaller to insignificant effect that was seen in case of spindle rotation direction, or it could be new research. As an example, using different forming tools geometries. It could be due to deficiency of knowledge about the process parameters about in depth for example, forming tool types(using only rigid hemispherical

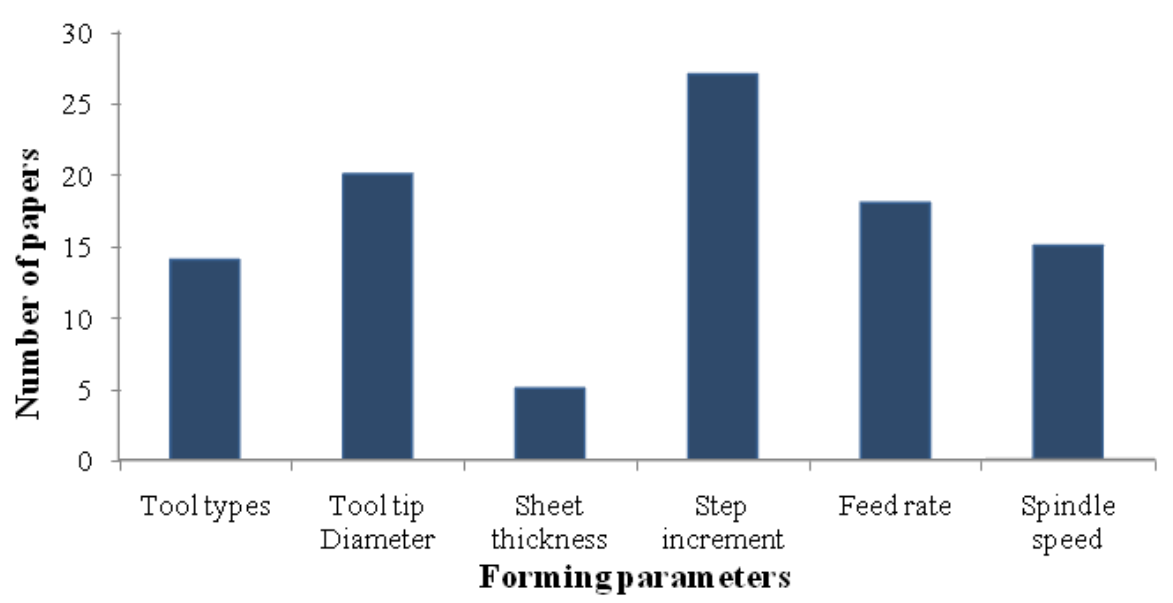

Fig. 13. Total number of papers effects on surface roughness 
Table 20. Incremental sheet forming process parameters framework

\begin{tabular}{|c|c|}
\hline Sr. No & ISF Parameters \\
\hline 1 & Tool types \\
\hline 2 & Tool diameter \\
\hline 3 & Tool material \\
\hline 4 & Sheet material type \\
\hline 5 & Sheet material thickness \\
\hline 6 & Material properties \\
\hline 7 & Step increment \\
\hline 8 & Feed rate \\
\hline 9 & Spindle rotation speed \\
\hline 10 & Lubrication Effects \\
\hline 11 & Spindle rotation direction \\
\hline 12 & Tool path strategy \\
\hline 13 & Clamping mechanism \\
\hline 14 & Experimental replications \\
\hline 15 & Forming machine specifications \\
\hline
\end{tabular}

forming tool) or due to rotational speed of spindle( using non rotated forming tools only).

\section{ISF PROCESS PARAMETERS IN SURVEY}

This quantitative evaluation in this survey paper permitted an understanding about the experimental data written into these journal articles. Some papers from this survey did not specify, for example, many papers carried out that uses experimental test replications that carried out material properties or value of spindle rotational speed. It is important to specify the whole exprimental aspects for forming process parameters like lubrication, missing from $25 \%$ of journal papers in this survey. Feed rate of $100 \mathrm{~mm} / \mathrm{min}$ and $3000 \mathrm{~mm} /$ min could have significantly various effects on responses due to heat produced during incremental sheet forming process.

The number of missed forming process parameters like lubrication, implied that full comparison between these paprameters is not possible. This requirment more attention of full broadness of forming process parameters that have an impact on incremental sheet forming process, or on important results mention in the papers.

A framework for important experimental data is suggested in Table 20. For any fundamental incremental sheet forming research also considering hot or electrically assisted incremental sheet forming processes. All these parameters provide an important information about incremental sheet forming for researchers.

\section{CONTRADICTORY RESULTS}

In this survey it observed that forming process parameters have inconsistent results. This delivers confirmation about the hypothesis of this survey work, especially that forming process factors are related, thus do not have stable effects during ISF process in all conditions.

Most important inconsistencies that observed while investigating the conclusions about the effect of forming tool diameter, instead of having large number of various journals articles that examined these forming parameters. The investigations demonstrate that various papers used different forming tool sizes and furthermore focus on forming tool types and important interaction between tool tip diameter and blank material thickness, also the interaction of tool diameter with step increment. Due to these reasons, number of papers was differing in their conclusions for forming tool diameter and forming tool geometries is not common. It provides direction for future researchers to consider the effect of interactions in forming process so that we can see more reliable conclusions about their collective impacts, and in this way set optimal choices in incremental sheet forming process.

\section{DISCUSSION AND CONCLUSIONS}

Based on extensive literature review, the aim of this paper is to foster deeper understanding regarding influence of incremental sheet forming tool geometries on surface roughness. Forming tool profiles and parametric interaction of various factors have received little academic attention. This study represents extensive understanding regarding the influence of forming tool profiles on surface finish , assisting in selection of best forming tool for specific forming operation and forming requirements.

Forming tool geometries and shapes are considered as pivotal attritubets of incremental sheet forming process. Results obtained after employing analysis of variance (ANOVA) represent the significant effect of tool shapes on surface roughness as hihglighted by its contribution of $36 \%$. Parabolic shape forming tools seemed to emabrk an outstanding effects on minimizaing the surface roughness for sheet metal forming. The reason for this finding is justified due to large angle side supporting the blank sheet or smothering scallop from forming tool step down. 
In order to obtain desired forming charateristics, it is recommended to form the part with flat end tool and then changing it to parabolic forming tool, leading to better surface finishing once surface angle has been set up. Further reseach is essentially required to analyze the effects which rolling ball end tools might impart on suface finish.

Studies have investigated various factors contributing to control the incremental sheet forming process in multiple experimentations form earlier stage of development [17]. An organized survey [13] was conducted to investigate the diversity among forming parameters and examined their effect on surface quality.

In this paper, information and results from various related papers were quantitatively represented including findings of sheet thickness, forming tool types, tool diameter, spindle rotation speed, feed rate and interactions between important process parameters. The finding imply that there are some important forming process parameters that are necessary to control each incremental sheet forming process including simple, hot or electric assisted forming process. Based on to this we considered only these fundamentals forming parameters and did not undertake parameters like temperature and current in this paper.

In incremental sheet forming (ISF) process most of the researchers used sheet thickness from $.5 \mathrm{~mm}$ to $2 \mathrm{~mm}$. The results from these investigations demonstrated that with increasing or decreasing of sheet thickness, surface quality improved. Optimization of sheet is important because with very large sheet thicknesses, outside form the range of values examined in majority of papers would start high challenge to form the parts with very high forming force and due to this surface roughness increase as shown with aluminum alloy (AA 3003-O) by Shanmuganatan et al. [32] and with aluminum alloy (AA 1100) having thickness $4 \mathrm{~mm}$ by Fang et al. [67]. This survey analyzed that influence of sheet thickness is reliable despite the effects of every sheet material may vary.

In incremental sheet forming (ISF) process most of the researchers used spindle speed in range of $100 \mathrm{rpm}$ to $1000 \mathrm{rpm}$. Based on sheet material type, spindle speed and feed should be optimized, also with the requirement of forming process time trade off. As spindle speed and feed would increase, surface finish during forming process would decrease. Analysis of variance (ANOVA) results showed that both spindle speed and feed rate have insignificant effect on roughness. In in- cremental sheet forming (ISF) feed rate can be selected above $1000 \mathrm{~mm} / \mathrm{min}$ to $6000 \mathrm{~mm} / \mathrm{min}$. Spindle rotation speed commonly considered the main consideration of producing heat from friction between forming tool and sheet. If heating advantages are required, then optimum setting of spindle speed is essential in order to stop forming surface damage as a result of friction between sheet and forming tool interface. It was found that forming time is independent of tool rotation speed. It was observed that at higher spindle speed, surface quality of formed parts increased. However it was observed up to specific level, after this surface roughness decreases and remained almost constant.

In incremnetal sheet forming (ISF) most of the researchers used step increment from $.2 \mathrm{~mm}$ to 1 $\mathrm{mm}$. The conclusions from this survey expressed that surface finish improved with decreasing in step increment. . Analysis of variance (ANOVA) results analyzed that step increment has also significant effect onsurface quality and has contribution up to $37 \%$. If less forming process time is required in in sheet forming process then value of step increment should be optimized. This illustrates that material requirments should be considered in order to select this process parameter and it also demonstrates the significnace of catering to utilize the interactions of step increment with tool diameter and sheet thickness.

Few papers were found in this survey that discussed about process parameters interactions. There is a strong interaction between spindle speed and feed rate due to friction between forming tool tip and blank sheet interface. Additionally, this interaction also affects frictional heating that might be valueable or unfavourable to this process, depending upon others forming parameters like sheet material type. An important interaction between forming tool diameter and sheet thickness which can significantly effect the surface roughness if the ratio between them is very large, investigated by Hussain et al. [63].

In conclusion of this survey paper, it has been observed that incremental sheet forming process parameters are not independent but are extremely interdependent.The results from this survey demonsterted that how important the selection of forming tool profile and others forming parameters that can bring optimal forming characteristics. A framework about incremental forming sheet parameters have been exhibited in order to confirm comparability between research in this direction in future. 


\section{REFERENCES}

1. Duflou, J., et al., Laser assisted incremental forming: formability and accuracy improvement. CIRP Annals-Manufacturing Technology, 2007. 56(1): p. 273-276.

2. Palumbo, G. and M. Brandizzi, Experimental investigations on the single point incremental forming of a titanium alloy component combining static heating with high tool rotation speed. Materials \& Design, 2012. 40: p. 43-51.

3. Adams, D. and J. Jeswiet, Single-point incremental forming of 6061-T6 using electrically assisted forming methods. Proceedings of the Institution of Mechanical Engineers, Part B: Journal of Engineering Manufacture, 2014. 228(7): p. 757-764.

4. Fan, G., et al., Electric hot incremental forming of Ti-6Al-4V titanium sheet. The International Journal of Advanced Manufacturing Technology, 2010. 49(9): p. 941-947.

5. Durante, M., A. Formisano, and A. Langella, Observations on the influence of tool-sheet contact conditions on an incremental forming process. Journal of materials engineering and performance, 2011. 20(6): p. 941-946.

6. Bagudanch, I., M. Sabater, and M.L. GarciaRomeu, Single Point versus Two Point Incremental Forming of thermoplastic materials. Advances in Materials and Processing Technologies, 2017. 3(1): p. 135-144.

7. Deepak, S.S., COMPUTER AIDED MANUFACTURING FACTORS AFFECTING REDUCTION OF SURFACE ROUGHNESS AND THICKNESS IN INCREMENTAL SHEET FORMING PROCESS. COMPUTER, 2017. 4(07).

8. Gulati, V., et al., Process parameters optimization in single point incremental forming. Journal of The Institution of Engineers (India): Series C, 2016. 97(2): p. 185-193.

9. Shanmuganatan, S. and V. Senthil Kumar. An experimental investigation on profile forming of an end cap using Al 3003 (O). in Advanced Materials Research. 2011. Trans Tech Publ.

10. Li, Y., et al., Simulation and experimental observations of effect of different contact interfaces on the incremental sheet forming process. Materials and Manufacturing Processes, 2014. 29(2): p. 121-128.

11. Cawley, B., D. Adams, and J. Jeswiet, Examining tool shapes in single point incremental forming. Proc NAMRI/SME, 2012. 26: p. 201-206.

12. Adams, D.W., Improvements on single point incremental forming through electrically assisted forming, contact area prediction and tool development. 2014: Queen's University (Canada).

13. Pickering, C. and J. Byrne, The benefits of publish- ing systematic quantitative literature reviews for $\mathrm{PhD}$ candidates and other early-career researchers. Higher Education Research \& Development, 2014. 33(3): p. 534-548.

14. Ham, M. and J. Jeswiet, Single point incremental forming and the forming criteria for AA3003. CIRP Annals-Manufacturing Technology, 2006. 55(1): p. 241-244.

15. Ham, M. and J. Jeswiet, Forming limit curves in single point incremental forming. CIRP Annals-Manufacturing Technology, 2007. 56(1): p. 277-280.

16. Shim, M.-S. and J.-J. Park, The formability of aluminum sheet in incremental forming. Journal of Materials Processing Technology, 2001. 113(1): p. 654-658.

17. Kim, Y. and J. Park, Effect of process parameters on formability in incremental forming of sheet metal. Journal of materials processing technology, 2002. 130: p. 42-46.

18. Petek, A., et al., Comparison of alternative approaches of single point incremental forming processes. Journal of materials processing technology, 2009. 209(4): p. 1810-1815.

19. Cavaler, L., et al., Surface roughness in the incremental forming of AISI 304L stainless steel sheets. J. Mechan. Eng. Phys, 2010. 1(2): p. 87-98.

20. Prashant, M., et al., Single Point Incremental Sheet Forming By CNC Vertical Milling Machine. Imperial Journal of Interdisciplinary Research, 2016. 2(11).

21. Pengtao, S., et al., Research on the Influencing Factors of" Scale Veins" of Single Point Incremental Forming Workpieces Surface. Open Mechanical Engineering Journal, 2015. 9: p. 1025-1032.

22. Khare, U. and M. Pandagale, A review of fundamentals and advancement in incremental sheet metal forming. IOSR Journal of Mechanical and Civil Engineering, 2014: p. 42-46.

23. Ziran, X., et al., The performance of flat end and hemispherical end tools in single-point incremental forming. The International Journal of Advanced Manufacturing Technology, 2010. 46(9): p. 1113-1118.

24. Lu, B., et al., Mechanism investigation of frictionrelated effects in single point incremental forming using a developed oblique roller-ball tool. International Journal of Machine Tools and Manufacture, 2014. 85: p. 14-29.

25. Ham, M., B. Powers, and J. Loiselle. Surface topography from single point incremental forming using an acetal tool. in Key Engineering Materials. 2013. Trans Tech Publ.

26. Chinnaiyan, P. and A. Jeevanantham, Multi-objective optimization of single point incremental sheet forming of AA5052 using Taguchi based grey relational analysis coupled with principal component analysis. International journal of precision engineer- 
ing and manufacturing, 2014. 15(11): p. 2309-2316.

27. Yazar, K., P. Date, and K. Narasimhan, Experimental studies on single point incremental forming of metallic sheets.

28. Jeswiet, J., et al., Single point and asymmetric incremental forming. Advances in Manufacturing, 2015. 3(4): p. 253-262.

29. Bhattacharya, A., et al., Formability and surface finish studies in single point incremental forming. Journal of manufacturing science and engineering, 2011. 133(6): p. 061020.

30. Kurra, S. and S. Regalla, Multi-objective optimisation of single point incremental sheet forming using Taguchi-based grey relational analysis. International Journal of Materials Engineering Innovation, 2015. 6(1): p. 74-90.

31. Radu, C., Effects of Process Parameters on the Quality of Parts Processed by Single Point Incremental Forming. Int. J. Mod. Manuf. Technol, 2011. 3(2): p. 91-96.

32. Shanmuganatan, S. and V.S. Kumar, Metallurgical analysis and finite element modelling for thinning characteristics of profile forming on circular cup. Materials \& Design, 2013. 44: p. 208-215.

33. Radu, C., et al., The effect of residual stresses on the accuracy of parts processed by SPIF. Materials and Manufacturing Processes, 2013. 28(5): p. 572-576.

34. Li, X., et al. Single-point incremental forming of 2024-T3 aluminum alloy sheets. in AIP Conference Proceedings. 2013. AIP.

35. Jagtap, R., et al., An experimental study on the influence of tool path, tool diameter and pitch in single point incremental forming (SPIF). Advances in Materials and Processing Technologies, 2015. 1(3-4): p. 465-473.

36. Malwad, D. and V. Nandedkar, Deformation mechanism analysis of single point incremental sheet metal forming. Procedia Materials Science, 2014. 6: p. 1505-1510.

37. Liu, Z., et al., Modeling and optimization of surface roughness in incremental sheet forming using a multi-objective function. Materials and Manufacturing Processes, 2014. 29(7): p. 808-818.

38. Strano, M., Technological representation of forming limits for negative incremental forming of thin aluminum sheets. Journal of manufacturing processes, 2005. 7(2): p. 122-129.

39. Jeswiet, J., et al., Asymmetric single point incremental forming of sheet metal. CIRP Annals-Manufacturing Technology, 2005. 54(2): p. 88-114.

40. Le, V., A. Ghiotti, and G. Lucchetta, Preliminary studies on single point incremental forming for thermoplastic materials. International Journal of Material Forming, 2008. 1: p. 1179-1182.
41. Jackson, K., J. Allwood, and M. Landert, Incremental forming of sandwich panels. Journal of Materials Processing Technology, 2008. 204(1): p. 290-303.

42. Arfa, H., R. Bahloul, and H. BelHadjSalah, Finite element modelling and experimental investigation of single point incremental forming process of aluminum sheets: influence of process parameters on punch force monitoring and on mechanical and geometrical quality of parts. International journal of material forming, 2013. 6(4): p. 483-510.

43. Jeswiet, J., E. Hagan, and A. Szekeres, Forming parameters for incremental forming of aluminium alloy sheet metal. Proceedings of the Institution of Mechanical Engineers, Part B: Journal of Engineering Manufacture, 2002. 216(10): p. 1367-1371.

44. Hagan, E. and J. Jeswiet, Analysis of surface roughness for parts formed by computer numerical controlled incremental forming. Proceedings of the Institution of Mechanical Engineers, Part B: Journal of Engineering Manufacture, 2004. 218(10): p. 1307-1312.

45. Attanasio, A., E. Ceretti, and C. Giardini, Optimization of tool path in two points incremental forming. Journal of Materials Processing Technology, 2006. 177(1): p. 409-412.

46. Desai, B.V., K.P. Desai, and H.K. Raval, Die-Less rapid prototyping process: Parametric investigations. Procedia Materials Science, 2014. 6: p. 666-673.

47. Patel, J.R., et al., Analysis of Variance for Surface Roughness Produced During Single Point Incremental Forming Process. Analysis, 2015. 2(3).

48. Khazaali, H., Determining frustum depth of 304 stainless steel plates with various diameters and thicknesses by incremental forming. Journal of Mechanical Science and Technology, 2014. 28(8): p. 3273-3278.

49. Uttarwar, P., S. Raini, and D. Malwad, Optimization of process parameter on Surface Roughness (Ra) and Wall Thickness on SPIF using Taguchi method. International Research Journal of Engineering and Technology, 2015.

50. Mulay, A.S. and R. Navthar, Experimental and numerical studies on single point incremental forming of commercial aluminum alloy.

51. Lu, H., et al., Study on step depth for part accuracy improvement in incremental sheet forming process. Advanced Materials Research, 2014(939).

52. Lasunon, O.U. Surface roughness in incremental sheet metal forming of AA5052. in Advanced Materials Research. 2013. Trans Tech Publ.

53. Rattanachan, K. and C. Chungchoo. The Effected of Single Point Incremental Forming Process Parameters on the Formed Part Surface Roughness. in Advanced Materials Research. 2014. Trans Tech Publ. 
54. Bermudez Paramo, G.J., F.A. Bustamante-Correa, and A.J. Benitez-Lozano, STatistical analysis of the main incremental forming process parameters that contribute to change the roughness in an experimental geometry. DYNA-Ingeniería e Industria, 2016. 91(6).

55. Mugendiran, V., A. Gnanavelbabu, and R. Ramadoss, Parameter optimization for surface roughness and wall thickness on AA5052 Aluminium alloy by incremental forming using response surface methodology. Procedia Engineering, 2014. 97: p. 1991-2000.

56. Silva, P.J., L.M. Leodido, and C.R.M. Silva. Analysis of incremental sheet forming parameters and tools aimed at rapid prototyping. in Key Engineering Materials. 2013. Trans Tech Publ.

57. Shah, H. and S. Chaudhary, Optimization of process parameters for incremental sheet forming process. International Journal for Technological Research in Engineering. 3(7): p. 2347-4718.

58. Rattanachan, K. and C. Chungchoo, Formability in single point incremental forming of dome geometry. AIJSTPME, 2009. 2(4): p. 57-63.

59. Petek, A., K. Kuzman, and J. Kopac, Deformations and forces analysis of single point incremental sheet metal forming. Archives of Materials science and Engineering, 2009. 35(2): p. 35-42.

60. Davarpanah, M.A., et al., Effects of incremental depth and tool rotation on failure modes and microstructural properties in Single Point Incremental Forming of polymers. Journal of materials processing technology, 2015. 222: p. 287-300.
61. Obikawa, T., S. Satou, and T. Hakutani, Dieless incremental micro-forming of miniature shell objects of aluminum foils. International Journal of Machine Tools and Manufacture, 2009. 49(12): p. 906-915.

62. Xu, D., et al., Mechanism investigation for the influence of tool rotation and laser surface texturing (LST) on formability in single point incremental forming. International Journal of Machine Tools and Manufacture, 2013. 73: p. 37-46.

63. Hussain, G., L. Gao, and N. Hayat, Forming parameters and forming defects in incremental forming of an aluminum sheet: correlation, empirical modeling, and optimization: part A. Materials and Manufacturing Processes, 2011. 26(12): p. 1546-1553.

64. Bagudanch, I., et al., Forming force and temperature effects on single point incremental forming of polyvinylchloride. Journal of materials processing technology, 2015. 219: p. 221-229.

65. Manco, G. and G. Ambrogio, Influence of thickness on formability in 6082-T6. International Journal of Material Forming, 2010. 3: p. 983-986.

66. Silva, M.B., et al., Failure mechanisms in singlepoint incremental forming of metals. The International Journal of Advanced Manufacturing Technology, 2011. 56(9-12): p. 893-903.

67. Fang, Y., et al., Analytical and experimental investigations on deformation mechanism and fracture behavior in single point incremental forming. Journal of Materials Processing Technology, 2014. 214(8): p. 1503-1515. 